\title{
SuPPly ChAINS AND BULLWHIP EFFECT
}

\section{Buchmeister, B.; PAlcic, I., PAVlinjeK, J. \& Polajnar, A.}

Abstract: Overall supply chain evaluation needs to include the Bullwhip Effect. The Bullwhip Effect shows how small changes at the demand end of a supply chain are progressively amplified for operations further back in the chain. It is understood that demand forecast variance contributes to that effect in the chain. With this understanding, the authors experimented with two cases: stable demand with a single $5 \%$ change in demand, and changing demand in periodic $10 \%$ increases and later in the same decreases. Two stock keeping policies for all stages in the chain have been studied: to keep in stock i) one, and ii) two periods' demand. Results are shown in tables and charts. Increasing variability of production orders and stocks up the supply chain is evident. The effect indicates a lack of synchronization among supply chain members because of corrupt key information about actual demand. When we understand the nature of supply chain dynamics, there are several actions concerned with coordinating the activities of the operations in the chain, which is discussed in the last part of the paper.

Key words: supply chain, bullwhip effect, production rate variability, variability of stocks, elimination
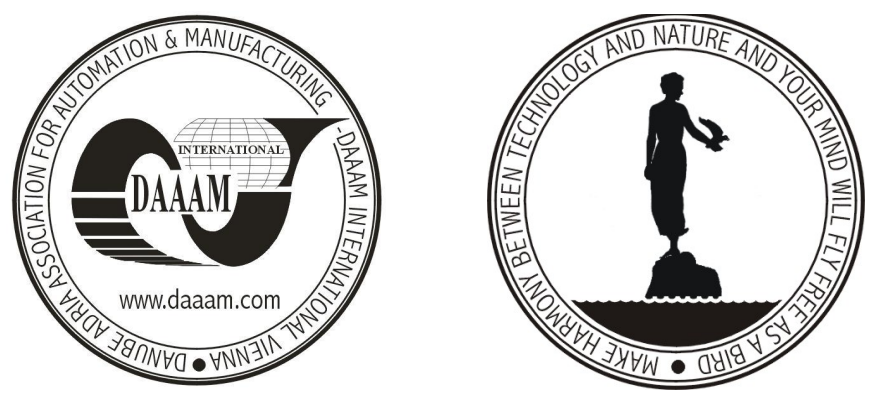

Authors' data: Dr. Sc. Buchmeister, B[orut]*; Ph.D. Ass. Prof. Palcic, I[ztok]*, B.Sc. Pavlinjek, [Joze]**, Dr. Sc. Polajnar, A[ndrej]*, * University of Maribor, Faculty of Mechanical Engineering, Smetanova 17, SI - 2000 Maribor, Slovenia, ** INOKS d.o.o., Goricka ulica 150, Cernelavci, SI-9000 Murska Sobota, Slovenia, borut.buchmeister@uni-mb.si, iztok.palcic@uni-mb.si,jp@inoks.si, andrej.polajnar@uni-mb.si

This Publication has to be referred as: Buchmeister, B.; Palcic, I., Pavlinjek, J. \& Polajnar, A. (2007). Supply Chains and Bullwhip Effect, Chapter 02 in DAAAM International Scientific Book 2007, B. Katalinic (Ed.), Published by DAAAM International, ISBN 3-901509-60-7, ISSN 1726-9687, Vienna, Austria

DOI: $10.2507 /$ daaam.scibook.2007.02 